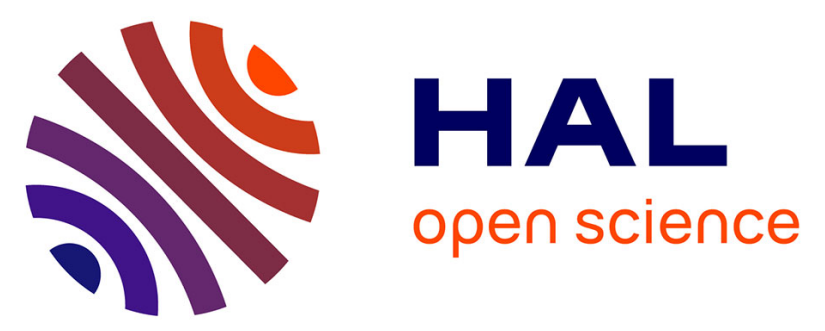

\title{
Additional Clues for a Protective Role ofVitamin D in Neurodegenerative Diseases: 1,25-Dihydroxyvitamin D3 Triggers an Anti-Inflammatory Response in BrainPericytes
}

Marie-France Nissou, Audrey Guttin, Cyril Zenga, François Berger, Jean-Paul Issartel, Didier Wion

\section{To cite this version:}

Marie-France Nissou, Audrey Guttin, Cyril Zenga, François Berger, Jean-Paul Issartel, et al.. Additional Clues for a Protective Role ofVitamin D in Neurodegenerative Diseases: 1,25-Dihydroxyvitamin D3 Triggers an Anti-Inflammatory Response in BrainPericytes. Journal of Alzheimer's Disease, 2014, pp.789-99. 10.3233/JAD-140411 . inserm-01199883

\section{HAL Id: inserm-01199883 https://www.hal.inserm.fr/inserm-01199883}

Submitted on 16 Sep 2015

HAL is a multi-disciplinary open access archive for the deposit and dissemination of scientific research documents, whether they are published or not. The documents may come from teaching and research institutions in France or abroad, or from public or private research centers.
L'archive ouverte pluridisciplinaire HAL, est destinée au dépôt et à la diffusion de documents scientifiques de niveau recherche, publiés ou non, émanant des établissements d'enseignement et de recherche français ou étrangers, des laboratoires publics ou privés. 
Additional Clues for a Protective Role ofVitamin D in Neurodegenerative Diseases:

1,25-Dihydroxyvitamin D3 Triggers anAnti-Inflammatory Response in BrainPericytes

Marie-France Nissou ${ }^{a, b, d, 1}$, Audrey Guttin ${ }^{b, c, e, 1}$, Cyril Zenga $^{a}$, François Berger ${ }^{a, b, c, d}$, Jean-Paul Issartel $\left.\right|^{\mathrm{b}, \mathrm{c}, \mathrm{f}, 1}$ and Didier Wion ${ }^{\mathrm{a}, \mathrm{b}, 1,1, *}$

aINSERM U1167, CLINATEC, Centre de Recherche Edmond I Safra, MINATEC Campus CEA, Grenoble, France

${ }^{\mathrm{b}}$ INSERM U836, Grenoble Institut des Neurosciences, Team Nanomedicine and Brain, Grenoble, France 'University of Grenoble Alpes, Grenoble, France

${ }^{\mathrm{d}} \mathrm{CHU}$ de Grenoble and Institut de Biologie et Pathologie, Grenoble, France

${ }^{e}$ CaCYS, EHPE, CNRS, UJF, Grenoble, France

${ }^{\mathrm{f}} \mathrm{CNRS}$, Grenoble, France

Abstract. Epidemiological and experimental studies suggest that 1,25-dihydroxyvitamin D3 (1,25D) plays a neuroprotectiverole in neurodegenerative diseases including Alzheimer's disease. Most of the experimental data regarding the genes regulatedby this hormone in brain cells have been obtained with neuron and glial cells. Pericytes play a critical role in brain function thatencompasses their classical function in blood-brain barrier control and maintenance. However, the gene response of brain pericyteto 1,25D remains to be investigated. Analyses of the transcriptomic response of human brain pericytes to $1,25 \mathrm{D}$ demonstrate thathuman brain pericytes in culture respond to $1,25 \mathrm{D}$ by regulating genes involved in the control of neuroinflammation. In addition,ericytes respond to the pro-inflammatory cytokines tumor necrosis factor aand Interferon $\gamma$ by inducing the expression of theCYP27B1 gene which is involved in 1,25D synthesis. Taken together, these results suggest that neuroinflammation could triggerthe synthesis of $1,25 \mathrm{D}$ by brain pericytes, which in turn respond to the hormone by a global anti-inflammatory response. Thesefindings identify brain pericytes as a novel 1,25D-responsive cell type and provide additional evidence for the potential value ofvitamin $D$ in the prevention or therapy of Alzheimer's disease and other neurodegenerative/neuropsychiatric diseases associatedwith an inflammatory component. 


\section{INTRODUCTION}

Recent data suggest a role for 1,25 dihydroxyvitaminD3 (1,25D) in the prevention or in the therapy of neurodegenerative and neuropsychiatric diseasesincluding multiple sclerosis and Alzheimer's disease(AD) (for recent reviews, see [1-10]). 1,25D is a secosteroidhormone produced from vitamin D througha two-step hydroxylation process successively producing25-hydroxyvitamin D3 (25D) and vitaminD's most active metabolite $1,25 \mathrm{D}$. This last stepis catalyzed by the 25 -Hydroxyvitamin D3 1alpha-Hydroxylase named CYP27B1. Inactivation of 1,25Doccurs through another hydroxylation step catalyzedby the vitamin D 24-Hydroxylase named CYP24A1, and generating 1,24,25trihydroxyvitamin D3 [11, 12].1,25D regulates the transcription of its cell specifictarget genes by interacting with a protein named vitaminD receptor (VDR). The presence of VDR in brain[13-16], the capacity of 1,25D to regulate the expressionof neurotrophic factors (for reviews, see [17]), and its anti-inflammatory potential $[2,18]$ are strongarguments in favor of a role for $1,25 \mathrm{D}$ in brain function. Regarding brain diseases, many recent studiesreport an association between vitamin $D$ insufficiencyand neurodegenerative/neuropsychiatric disorders $[5,7,10,19,20]$. Experimental evidence also demonstratea preventive or therapeutic potential for 1,25Din brain disorders including multiple sclerosis, Parkinson'sdisease, AD, and traumatic brain injury (forrecent reviews, see [21-24]). Investigating the generesponse to vitamin $D$ in brain cells is critical forunderstanding the molecular basis of its neuroprotectiveeffect. Most of the experimental data regarding thepotential of 1,25D to regulate the expression of genesable to prevent or delay the progression of neurodegenerativediseases have been obtained in vitro usingbrain-derived cells. These include neurons and macroor microglial cells (see [25-32]). However, little attentionhas been given to another abundant brain cell type,the brain pericyte.Pericytes are microvessel cells that wrap aroundendothelial cells [33-35]. The pericyte-to-endotheliaratio is $1: 3$, and the total length of capillaries inhuman brain is around 400 miles [36, 37]. The edge-toedgeinter-microvessels distance in rat brain is around $20 \mu \mathrm{m}$ in gray matter and $30 \mu \mathrm{m}$ in white matter [38].This means that pericytes are very close to everyneuronal cell. Because of their perivascular localization, pericytes are components of the neurovascularunit (NVU), an anatomical and functional entity associatingneurons, glial and immune cells, endothelialcells, pericytes, and the extracellular matrix [33-35,39, 40]. How brain pericytes communicate with glialand neuronal cells in NVU is still largely unknown, but they are, however, essential for proper functionsof neurons [36, 41]. In addition to their role in angiogenesis,vessel maintenance, and blood-brain barrierformation and functions [33, 35], brain pericytes alsocontribute to immune and inflammatory responsesby synthesizing pro-inflammatory cytokines includingCXCL8/IL-8, CXCL11/ITAC, CCL5/Rantes, tumornecrosis factor-alpha (TNF- $\alpha$ ), interleukin-1 $\beta($ IL-1 $\beta$ ), and interleukin-6 (IL-6) [42]. They participate to theadaptive immune response [43] and also have animmunosuppressive function by decreasing T lymphocyte proliferation [44]. The importance of pericytesin brain function is assessed by the observation thatage-dependent vascular damage in pericyte-deficientmice precedes neuronal degenerative changes, learningimpairment, memory deficiency, and the neuroinflammatoryresponse [41]. Pericyte loss or dysfunctioninfluences multiple steps of $A D$ in several experimentalmodels [36, 41, 45]. Hence, targeting brain pericyteis now considered as a novel therapeutic option for $\operatorname{AD}[39,41,45,46]$. The emerging evidence for arole of vitamin $D$ in brain function and its potentialpreventive and therapeutic interest in the managementof neurodegenerative disease prompted us to analyzethe transcriptomic response of human brain pericyte to1,25D. Our results provide evidence for a functionalrelationship between vitamin $\mathrm{D}$ and pericytes in thecontrol of inflammation that could explain some ofthe antiinflammatory and neuroprotective effects ofvitamin D. 


\section{MATERIAL AND METHODS}

\section{Cell culture}

Human brain pericytes and human brain endothelialcells were obtained from ScienCell Research Laboratories(San Diego, CA, USA). Cells were culturedon poly-lysine coated culture dishes according tothe provider instructions. Briefly, the growth mediumfor pericytes was made with Pericyte Basal CultureMedium supplemented with 2\% fetal bovineserum, with Pericyte Cell Growth Supplement andwith penicillin and streptomycin, all from Science-Cell Research Laboratories (San Diego, CA, USA).

Brain endothelial cells were cultured in EndothelialBasal Culture Medium supplemented with EndothelialGrowth Supplement and with penicillin and streptomycin,all from ScienCell Research Laboratories. Inthe absence of a definitive pan-marker for pericytes, immunophenotyping of pericytes relies on the use of apanel of different markers [34]. Positive markers caninclude PDGFR $\beta$, nestin, and CD13/aminopeptidaseN, whereas Ve-Cad can be used as a negative marker. Immunophenotyping of our cell cultures demonstrateda homogeneous positive labelling forPDGFR_, nestin,CD13/aminopeptidase $\mathrm{N}$ and no detectable synthesisof the endothelial marker VE-Cadherin (SupplementaryFig. 1A-D). On the contrary, brain endothelialcells stained positively for the endothelial markerVE-Cadherin (Supplementary Fig. 1E). TNF- $\alpha$ andInterferon- $\gamma$ (Peprotech, Neuillysur-Seine, France)were used at $50 \mathrm{ng} / \mathrm{ml}$.

\section{Western blot analysis}

For western blot analysis, cell pellets were resuspendedand lysed in RIPA buffer (Cell Signaling Technology, Danvers, USA) supplemented with completeProtease Inhibitor Cocktail (Cell Signaling Technology, Danvers, USA). The proteins ( $40 \mu \mathrm{g})$ were resolved with $8 \%$ polyacrylamide gel and transferredonto the Hybond $\mathrm{N}+$ membrane (Amersham, Velizy-Villacoublay, France) according to standardprotocols. Blots were then probed with the VDRantibody N20 (Santa Cruz, sc-1009) or D6 (SantaCruz, sc-13133), followed by incubation with thecorresponding horseradish peroxidase conjugated secondaryantibodies (Santa Cruz, sc-2004 or sc-2005).

\section{$R N A$ extraction and $R T-q P C R$}

$2 \mu \mathrm{g}$ of total RNA were transcribed intocDNA using iScriptTM Reverse TranscriptionSupermix for RT.qPCR (BioRad Laboratories, Marnes-la-Coquette, France). PCR primers(Eurogentec, Angers, France) for each gene weredesigned using the Universal ProbeLibrary AssayDesign Center (https://www.roche-applied-science.com/sis/rtpcr/upl/ezhome.html) and sequences of theprimers used are given as Supplementary Table 1.Then real-time PCRs were performed accordingto the SYBR Green methodology using theSsoAdvancedTM SYBRR Green Supermix (BioRadLaboratories, Marnesla-Coquette, France), on aCFX96 TouchTMReal-Time PCR Detection System (BioRadLaboratories, Marnes-la-Coquette, France).Reference genes are _ actin and glyceraldehyde-

3-phosphate dehydrogenase (GAPDH), whoseexpressions were not affected by 1,25D according to our Affymetrix data (data not shown). Analyses were performed as previously described [25] with CFX ManagerTM software (BioRad Laboratories, Marnes-la-Coquette, France) using _ Ct method. Each qPCR was performed in triplicate for PCR yieldvalidation and all reactions were performed on threedifferent biological samples. Data were quantifiedrelative to gene expressions of pericyte cells without1,25D treatment, which was standardized to 100.The statistical validation was given by the CFXManager software and $p<0.005$ was considered significant. 


\section{Gene expression profiling}

Total RNA (300 ng) extracted as described abovewas reverse transcribed and labelled with 3 prime IVTExpress kit (Affymetrix, High Wycombe, UK) followingthe manufacturer's instructions. Labelled sampleswere hybridized on GeneChipHumanGenomeU133Plus2.0 (Affymetrix, High Wycombe, UK). This microarray contains over 47,000 unique transcriptswhich correspond approximately to 39,000 human genes. Subsequent wash, stain, and scan wereperformed according to the standard Affymetrix protocols.Raw expression data were normalized usingthe Robust Multi-array Average method. Experimentswere repeated twice using different RNA sampleson GeneChip (Affymetrix, High Wycombe, UK) andcorroborated by RT-qPCR for genes of interest. Thetranscriptomic data have been deposited in NCBI'sGene Expression Omnibus and are accessible throughthe Gene Expression Omnibus accession numberGSE54765.

\section{RESULTS}

Pericytes express VDR and respond to 1,25D byinducing CYP24A1 expression

$1,25 \mathrm{D}$ regulates gene expression of its target genesby interacting with the nuclear receptor VDR.We firstinvestigated the presence of VDR in human brain pericyte.Western blot analysis of pericyte cell lysateswith the VDR polyclonal antibody N20 detected thepresence of a $53 \mathrm{kDa}$ band consistent with the presenceof VDR in these cells (Fig. 1A). A similar resultwas obtained with the VDR monoclonal antibody D6(Supplementary Fig. 2).We next determined the functionality of the 1,25D/VDR transduction pathway in human brain pericytesby analyzing CYP24A1 regulation by 1,25D(CYP24A1 is a well-known 1,25D-responsive gene[47]). Results presented in Fig. 1B demonstrate thestrong induction of CYP24A1 gene expression in pericytestreated for 24 hours with $10^{-8} \mathrm{M} 1,25 \mathrm{D}$.

\section{Brain pericyte transcriptomic response to $1,25 D$}

Having demonstrated the presence of VDR inhuman brain pericytes and the responsiveness of these cells to 1,25D, we analyzed the transcriptomicresponse of brain pericytes to 1,25D. RNA

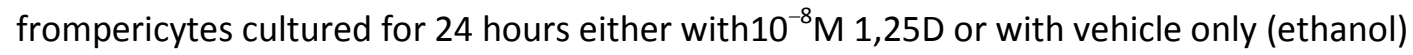
wereextracted and processed for transcriptomic analyses. Experiments were performed on two different RNApreparations for each condition. Twenty genes werefound upregulated by a factor of at least 1.7, and 5down-regulated genes were also detected (expressionratios lower than 0.7) (Table 1). Eight of these geneswere already described as 1,25D targets in cells otherthan pericytes. These genes are cytochrome P450A1(CYP24A1) [47], elongation factor Tu GTP bindingdomain (EFTUD1) [48], thrombomodulin (THBD)[49], odd-skipped related 2 (OSR2) [50], Kruppel-likefactor 4 (KLF4) [51], insulin-like growth factorbinding protein 5 (IGFBP5) [52], fatty acid binding protein 4 (FABP4) [53], and tumor necrosis factor(ligand) superfamily member 4 (TNFS4/OX40L)[54]. An analysis of the 25 genes found regulated by1,25D was carried out with the GeneDeck analysis tool (http://www.genecards.org/). This allowed theidentification of 14 disorders associated with this setof genes with a $p$ value lower than $10^{-5}$. Six of thesedisorders were inflammatory diseases: endotheliitis $\left(p=2.2 \times 10^{-10}\right)$, asthma $\left(p=1.4 \times 10^{-6}\right)$, rheumatoidarthritis $\left(p=2 \times 10^{-6}\right)$, arthritis $(p=$ $\left.5.1 \times 10^{-6}\right)$, inflammation $\left(p=6.4 \times 10^{-6}\right)$, and pancreatitis $\left(p=1.1 \times 10^{-5}\right)$. The other disorders include variouscancers and hypertension. To confirm the relationshipexisting between the transcriptomic response of brainpericytes to 1,25D and inflammation, a bibliographicsearch in PubMed associating each of these 25 genes with the keyword "inflammation" was done. Relevant results were obtained for 8 genes. These genes arevascular cell adhesion molecule 1 (VCAM1), THBD,KLF4, tumor necrosis factor alpha-induced protein6 (TNFAIP6), chordin-like 1 (CHRDL1), 
chemokine(C-C motif) ligand 2 (CCL2), FABP4, tumor necrosisfactor (ligand) superfamily member 4 (TNFSF4).THBD, KLF4, FABP4, and TNFSF4 have alreadybeen described as 1,25D-responsive genes in cellsother than brain cells or pericytes $[49,51,53,54]$.Confirmatory RT-qPCR analyses were performed thatvalidated the transcriptomic data for the 4 remaininggenes which were not previously described as 1,25Dtargets (Fig. 2). These are CCL2, CHDRL1, TNFPAIP6, and VCAM-1. KLF4 and TNFSF4 were alsoincluded as positive controls in these confirmatory experiments. Importantly the regulations observed areconsistent with a global anti-inflammatory response(see discussion below).

Induction of CYP27B1 expression by thepro-inflammatory cytokines TNF- $\alpha$ andinterferon- $\gamma$ $25 \mathrm{D}$ is the most abundant metabolite of vitamin Din the circulation, but the most active metabolite is $1,25 \mathrm{D}[11,12]$. Hydroxylation of $25 \mathrm{D}$ to active $1,25 \mathrm{Dis}$ required for the induction of the 1,25Ddependentsignaling pathway [11, 12]. This reaction is carriedout by 25 -Hydroxyvitamin D3 1alphaHydroxylaseCYP27B1, the rate limiting enzyme in 1,25D synthesis.Analysis of our transcriptomic data for CYP27B1failed to detect any expression for this gene in our pericytecultures (data not shown). Considering the globalanti-inflammatory gene response of pericytes to 1,25D, we hypothesized that inflammatory stimuli could upregulateCYP27B1 gene expression in these cells. Thiswould allow pericytes to metabolize 25D into 1,25Dand then limit the inflammatory response locally. Toinvestigate this point we treated brain pericytes withTNF- $\alpha$ and Interferon- $\gamma$ which were recently foundto upregulate CYP27B1 in astrocytes [55]. Figure 3showed that a treatment of pericytes for 24 hourswith these two inflammatory cytokines stimulated theexpression of CYP27B1.

\section{DISCUSSION}

Epidemiological studies reveal a relationshipbetween several neurodegenerative/psychiatric diseasesand low vitamin D levels $[5,7,10,19-21,57,58]$. Although association does not mean causation, the possible role of vitamin $D$ as a protectiveco-factor against brain disorders is further supportedby data demonstrating the neuroprotective effect ofvitamin D or of its active metabolite $1,25 \mathrm{D}$ in severalexperimental models of brain diseases (for recent reviews, see [1-10]). Understanding the molecularpathways involved in these effects is critical for optimizingclinical trials. At the transcriptomic level,1,25D is already known to upregulate several genes relevant to neuroprotection in brain cells. Several ofthese genes encode neurotrophins including NGF andGDNF [59-61]. 1,25D is a potent immunoregulatoryagent [2-4, 62, 63]. In neurons or glial cells1,25D regulates the expression of genes involved in thecontrol of neuroinflammation, such as cystathioninebeta-synthase, which codes for the enzyme producing the neuroprotective agent hydrogene sulfide [25], andgamma-glutamyltranspeptidase (gamma-GT) whichis the enzyme that synthesizes the antioxidant glutathione[64]. 1,25D also reduces the expression of theinflammatory cytokines M-CSF and TNF-_ in astrocyteschallenged with lipopolysaccharides [65], andprotects brain cells from nitric oxide excessive productionby down-regulating iNOS [30]. However, allthese data have been obtained with cells others thanpericytes, and the global gene response of pericytes to1,25D remained to be investigated. This point is criticalregarding the importance of pericytes in brain function[33-46]. The present study reveals that eight out of thetwenty five genes we found regulated by $1,25 \mathrm{D}$ in brainpericytes are related to inflammation. With exceptionof VCAM1, all of these genes are involved in criticalanti-inflammatory processes. This regulation is consistentwith a global anti-inflammatory process sincepro-inflammatory genes are found down-regulated,while antiinflammatory genes are upregulated. 
Pro-inflammatory genes down-regulated by 1,25Din pericytes

CCL2/MCP-1 is an inflammatory chemokine thatis also able to modulate blood-brain barrier permeability.It is upregulated in $A D$ patients and notablyin brain microvessels [66]. High plasma concentration of CCL2 are found in mild $A D$ [67] and is associatedwith a faster rate of cognitive decline during the earlystages of AD [68]. CCL2 is also associated with multiplesclerosis patients and experimental autoimmuneencephalomyelitis (EAE). Moreover deficiency in theCCL2 receptor CCR2 confers resistance to EAE [69].TNFSF4/OX40L is the ligand of the OX40 receptor. The OX40-OX40L interaction is critical for theregulation of $\mathrm{T}$ cell tolerance and T-cell mediatedinflammatory diseases [70]. Consequently, OX40 signalingis involved in allergic inflammation [71, 72] and in multiple sclerosis, and is also involved inthe development of EAE [73]. Down-regulation ofTNFSF4/OX40L is suggested to provide a novelapproach for treating inflammatory disease [72,

74-76].The fatty acid binding protein FABP4 acts at theinterface of metabolic and inflammatory pathways[77]. It is involved in the development of a chronicmetabolic inflammatory state recently referred asmetaflammation that connects obesity with inflammation[77]. FABP4 is associated with inflammatoryfactors relatedto obesity [78], and is also implicated in asthma [79] and rheumatoid arthritis [80]. Toour knowledge, the involvement of FABP4 and the potential of inhibitors of FABP4 have not yet beeninvestigated in inflammatory neurodegenerative disorders.

\section{Anti-inflammatory genes upregulated by $1,25 D$ inpericytes}

Thrombomodulin (THBD) is a well characterized1,25D responsive gene proposed as a biomarker for evaluating the effect of vitamin $D$ supplementation[49]. The anti-inflammatory properties of thrombomodulinhave been recently reviewed $[81,82]$. THBDsequesters thrombin which has proinflammatoryactivities, in addition to its role in hemostasis andthrombosis. Note that thrombin is highly expressed inAD brain vessels and is a mediator of cerebral inflammation in AD.

Thrombomodulin also promotes theactivation of protein $\mathrm{C}$, which, in addition to its anticoagulant activity, also has anti-inflammatory effectsby suppressing the production of the pro-inflammatory cytokine TNF- $\alpha$ [83].Tumor necrosis factor, alpha-induced protein 6(TNFAIP6/TSG6) is a secreted protein whose expressionis upregulated in response to pro-inflammatorycytokines such as TNF and IL-1. It has anti-inflammatory effects and acts as a negative feedbackmodulator by down-regulating the inflammatoryresponse [84].The identification of KLF4 as a 1,25D upregulatedgene is in agreement with a previous findingobtained with keratinocytes [51] and is in line witha general role of 1,25D and KFL4 in the controlof inflammatory responses. KLF4 inhibits endothelialinflammation [85] and represses the expression ofhistidine carboxylase, which is the enzyme that convertshistidine to histamine, a major actor of allergyand inflammation [86]. In macrophage KLF4 promotesthe antiinflammatory macrophage/microglia M2 phenotype at the expanse of the M1 pro inflammatoryphenotype [87]. In this regard, it is worth mentioningthat M2 microglia is reported to drive oligodendrocytedifferentiation during CNS remyelination. Althoughsuch effects are observed with macrophages, they maybe relevant in the case of pericytes. Indeed these cellsare a source of macrophage activity, macrophage markers, phagocytosis, and antigen presentation [88]. Note,however, that KLF4 also increases the synthesis ofseveral pro-inflammatory cytokines in M1 microglialcells [89]. This suggests that the effects of 1,25Don KLF4 expression could participate to the control of abalanced inflammatory response, thus preventing the development of chronic inflammation. Chordin-like protein 1 (CHRDL1), also known asVentroptin, is a bone morphogenetic protein-4 antagonist[90, 91]. It antagonizes the function of BMP4 bybinding to it and preventing its interaction with receptors. Increased expression of BMP4 mRNA withinthe hippocampus dentate 
gyrus is correlated with adecrease in cell proliferation inA_PPswe/PS1DeltaE9transgenic mice [92]. BMP4 is upregulated duringEAE [93], and this cytokine is also reported to mediateinflammation in endothelial cells [94]. Hence, thesynthesis of CHRDL1 by pericytes would protect cells from inflammation.Vascular adhesion molecule-1 (VCAM1) is a cellsurface protein with adhesion properties. It is alymphocyte adhesion molecule induced on humanendothelium by inflammatory stimuli [95] and hasbeen initially considered as an inflammatory marker.However, it is not clear whether its function is onlydirected toward the aggravation of the original insultor if, depending of the context, is also involved inthe restoration of homeostasis. VCAM1 plays a keyrole in the brain in maintaining subventricular zoneadult stem cell niche structure and function [96]. Thissuggests that VCAM1 could have similar functions inthe maintenance of the structure and functions of theNVUby regulating cell-cell junctions. Upregulation ofVCAM1 has been suggested to play a protective role inmaintaining the integrity of the ependymal zone duringneuroinflammation [96]. VCAM-1 depletion leadsto the rapid decrease of the subventricular zone neuralstem cell population, suggesting that chronic VCAM-1insufficiency/deficiency would lead to neural stem celldepletion [96].

Collectively, our gene expression data providestrong evidence that the gene response of human brainpericytes to $1,25 \mathrm{D}$ is directed toward the control ofneuroinflammation.

\section{Expression of CYP27B1 in pericytes can beinduced by an inflammatory stimulus}

$1,25 \mathrm{D}$ results from the metabolism of 25D by 25 -Hydroxyvitamin D3 1alpha-Hydroxylase (CYP27B1). Thus, the availability of 1,25D at the cellular leveldepends on both circulating levels of 25D, and CYP27B1 expression level. 25D is detected in humancerebrospinal fluid [58]. Therefore, the characterizationof stimuli able to induce CYP27B1 is critical. Here we report that TNF- $\alpha$ and Interferon- $\gamma$, two inflammatory cytokines recently described to regulateCYP27B1 expression in astrocytes and microglial cells [55], also induce the expression of CYP27B1 in pericytes.

Note that pericytes are reported to secrete TNF- $\alpha$ [42]. Our data strongly suggest the existence of a regulatoryintracrine/autocrine feedback loop in pericytesbalancing the inflammatory potential of TNF- $\alpha$ andInterferon- $\gamma$. A paracrine role for the 1,25D producedby pericytes in the NVU during inflammation can alsobe considered.In conclusion, our results point to brain pericytes and $1,25 \mathrm{D}$ as two active players in the regulation of neuroinflammation. They provide additional evidence fora role of vitamin $D$ metabolites in the prevention and the therapy of neurodegenerative/neuropsychiatric diseasesthrough the modulation of neuroinflammation. They also strengthened the interest of targeting brainpericytes for controlling brain disorders such as $A D$ $[41,45,46,97,98]$.

\section{ACKNOWLEDGMENTS}

We thank Dr. A. Hihi for his critical reading of themanuscript. Authors' disclosures available online (http://www.jalz.com/disclosures/view.php?id=2286).

\section{SUPPLEMENTARY MATERIAL}

Supplementary material is available in the electronicversion of this article:

http://dx.doi.org/10.3233/JAD-140411.

\section{REFERENCES}

[1] Gezen-Ak D, Yılmazer S, Dursun E (2014) Why vitamin Din Alzheimer's disease? The hypothesis.J Alzheimers Dis 40, 257-269. 
[2] Fernandes de Abreu DA, Eyles D, Féron F (2009) Vitamin D, a neuro-immunomodulator: Implications for neurodegenerative and autoimmune diseases. Psychoneuroendocrinology34(Suppl 1), S265-S277.

[3] DeLuca GC, Kimball SM, Kolasinski J, Ramagopalan SV,Ebers GC (2013) Review: The role of vitamin D in nervoussystem health and disease. NeuropatholApp/Neurobio/39,458-484.

[4] Smolders J, Moen SM, Damoiseaux J, Huitinga I, Holmøy T(2011) Vitamin D in the healthy and inflamed central nervoussystem: Access and function. J NeurolSci311, 37-43.

[5] Balion C, Griffith LE, Strifler L, Henderson M, Patterson C,Heckman G, Llewellyn DJ, Raina P (2012) Vitamin $D$, cognition, and dementia: A systematic review and meta-analysis

[6] Kesby JP, Eyles DW, Burne THJ, McGrath JJ (2011) Theeffects of vitamin D on brain development and adult brainfunction. Mol Cell Endocrino/347, 121-127.

[7] Annweiler C, Montero-Odasso M, Llewellyn DJ, Richard-Devantoy S, Duque G, Beauchet O (2013) Meta-analysis ofmemory and executive dysfunctions in relation to vitamin D.J Alzheimers Dis 37, 147171.

[8] Soni M, Kos K, Lang IA, Jones K, Melzer D, Llewellyn DJ(2012) Vitamin D and cognitive function. Scand J Clin Lablnvest Supp/243, 79-82.

[9] Stewart A, Wong K, Cachat J, Elegante M, Gilder T, MohnotS, Wu N, Minasyan A, Tuohimaa P, Kalueff AV (2010) Neurosteroidvitamin D system as a nontraditional drug target inneuropsychopharmacology. BehavPharmaco/21, 420-426.

[10] Anglin RES, Samaan Z, Walter SD, McDonald SD (2013)Vitamin D deficiency and depression in adults: Systematicreview and meta-analysis. Br J Psychiatry J MentSci202,100-107.

[11] Holick MF (2007) Vitamin D deficiency. N Engl J Med 357,266-281.

[12] Norman AW (2008) From vitamin D to hormone D: Fundamentalsof the vitamin D endocrine system essential for goodhealth. Am J ClinNutr88, 491S-499S.

[13] Cui X, Pelekanos M, Liu P-Y, Burne THJ, McGrath JJ, Eyles DW (2013) The vitamin D receptor in dopamine neurons; itspresence in human substantia nigra and its ontogenesis in rat midbrain. Neuroscience 236, 77-87.

[14] Eyles DW, Smith S, Kinobe R, Hewison M, McGrathJJ (2005) Distribution of the vitamin D receptor and 1alpha-hydroxylase in human brain. J ChemNeuroanat29,21-30.

[15] Prüfer K, Veenstra TD, Jirikowski GF, Kumar R (1999) Distributionof 1,25-dihydroxyvitamin D3 receptor immunoreactivityin the rat brain and spinal cord. J ChemNeuroanat16,135-145.

[16] Stumpf WE, O'Brien LP (1987) 1,25 (OH)2 vitamin D3 sitesof action in the brain. An autoradiographic study.Histochemistry87, 393-406.

[17] Garcion E, Wion-Barbot N, Montero-Menei CN, Berger F, Wion D (2002) New clues about vitamin D functions in thenervous system. Trends EndocrinolMetab13, 100-105.

[18] Vanoirbeek E, Krishnan A, Eelen G, Verlinden L, BouillonR, Feldman D, Verstuyf A (2011) The anti-cancer and anti-inflammatory actions of 1,25(OH)2D3. Best Pract Res ClinEndocrinolMetab25, 593-604.

[19] Annweiler C, Llewellyn DJ, Beauchet O (2013) Low serumvitamin D concentrations in Alzheimer's disease: A systematicreview and meta-analysis. J Alzheimers Dis 33, 659-674.

[20] McGrath JJ, Burne TH, F'eron F, Mackay-Sim A, EylesDW (2010) Developmental vitamin D deficiency and risk ofschizophrenia: A 10-year update. Schizophr Bull 36, 1073-1078.

[21] Evatt ML (2014) Parkinson disease: Low vitamin D andParkinson disease-a causal conundrum. Nat Rev Neurol10,8-9. 
[22] Eyles DW, Burne THJ, McGrath JJ (2013) Vitamin D, effectson brain development, adult brain function and the linksbetween lowlevels of vitaminDand neuropsychiatric disease.Front Neuroendocrino/34, 47-64.

[23] Mesliniene S, Ramrattan L, Giddings S, Sheikh-AliM(2013)Role of vitamin D in the onset, progression, and severity ofmultiple sclerosis. EndocrPract19, 129-136.

[24] Stein DG, Cekic MM (2011) Progesterone and vitamin Dhormone as a biologic treatment of traumatic brain injury inthe aged. $P M R$ 3, S100-S110.

[25] Nissou M-F, Brocard J, El Atifi M, Guttin A, Andrieux A, Berger F, Issartel J-P, Wion D (2013) The transcriptomicresponse ofmixed neuron-glial cell cultures to1,25-dihydroxyvitamin D3 includes genes limiting the progression of neurodegenerative diseases. J Alzheimers Dis 35,553-564.

[26] Dursun E, Gezen-AkD,Yilmazer S (2013)Anewmechanismfor amyloid- $\beta$ induction of iNOS: Vitamin D-VDR pathwaydisruption. J Alzheimers Dis 36, 459-474.

[27] Neveu I, Naveilhan P, Jehan F, Baudet C, Wion D, De LucaHF, Brachet P (1994) 1,25dihydroxyvitamin D3 regulates thesynthesis of nerve growth factor in primary cultures of glialcells. Brain Res Mol Brain Res 24, 70-76.

[28] R'emy S, Naveilhan P, Brachet P, Neveu I (2001) Differentialregulation of GDNF, neurturin, and their receptors in primarycultures of rat glial cells. J Neurosci Res 64, 242-251.

[29] Naveilhan P, Neveu I, Baudet C, Funakoshi H, Wion D, BrachetP, MetsisM(1996) 1,25-

Dihydroxyvitamin D3 regulatesthe expression of the low-affinity neurotrophin receptor. Brain Res Mol Brain Res 41, 259-268.

[30] Garcion E, Nataf S, Berod A, Darcy F, Brachet P (1997) 1,25-Dihydroxyvitamin D3 inhibits the expression of induciblenitric oxide synthase in rat central nervous system during experimental allergic encephalomyelitis. Brain Res Mol BrainRes 45, 255-267.

[31] Correale J, Ysrraelit MC, Gait'an MI (2011) Vitamin Dmediatedimmune regulation in multiple sclerosis. J NeurolSci311, 23-31.

[32] Lefebvre d'Hellencourt C, Montero-Menei CN, BernardR, Couez D (2003) Vitamin D3 inhibits proinflammatorycytokines and nitric oxide production by the EOC13microglial cell line. J Neurosci Res 71, 575-582.

[33] Ballabh P, Braun A, Nedergaard M (2004) The blood-brainbarrier: An overview: Structure, regulation, and clinical implications.Neurobiol Dis 16, 1-13.

[34] Dore-Duffy P, Cleary K (2011) Morphology and propertiesof pericytes. Methods Mo/686, 49-68.

[35] D'ıaz-Flores L, Guti'errez R, Madrid JF, VarelaH,Valladares F,Acosta E, Mart'ın-VasalloP,D'ıaz-

Flores L Jr (2009) Pericytes.Morphofunction, interactions and pathology in a quiescent and activated mesenchymal cell niche. HistolHistopatho/24,909-969.

[36] Winkler EA, Bell RD, Zlokovic BV (2011) Central nervoussystem pericytes in health and disease. Nat Neurosci14, 1398-1405.

[37] Zlokovic BV (2008) The blood-brain barrier in health andchronic neurodegenerative disorders. Neuron 57, 178-201.

[38] Schlageter KE, Molnar P, Lapin GD, Groothuis DR(1999) Microvessel organization and structure in experimentalbrain tumors: Microvessel populations with distinctivestructural and functional properties. Microvasc Res 58,312-328.

[39] Stanimirovic DB, Friedman A (2012) Pathophysiology of theneurovascular unit: Disease cause or consequence? J CerebBlood Flow Metab32, 1207-1221.

[40] S'a-Pereira I, Brites D, Brito MA (2012) Neurovascular unit:A focus on pericytes. MolNeurobio/45, 327-347. 
[41] Bell RD, Winkler EA, Sagare AP, Singh I, LaRue B, DeaneR, Zlokovic BV (2010) Pericytes control key neurovascularfunctions and neuronal phenotype in the adult brain and duringbrain aging. Neuron 68, 409-427.

[42] Alcendor DJ, Charest AM, Zhu WQ, Vigil HE, KnobelSM (2012) Infection and upregulation of proinflammatorycytokines in human brain vascular pericytes by humancytomegalovirus. $J$

Neuroinflammation9, 95.

[43] Pober JS, Tellides G (2012) Participation of blood vessel cellsin human adaptive immune responses. Trends Immuno/33,49-57.

[44] Tu Z, Li Y, Smith DS, Sheibani N, Huang S, Kern T, Lin F(2011) Retinal pericytes inhibit activated T cell proliferation.Invest Ophthalmol Vis Sci52, 9005-9010.

[45] Sagare AP, Bell RD, Zhao Z, Ma Q,Winkler EA, RamanathanA, Zlokovic BV (2013) Pericyte loss influences Alzheimerlikeneurodegeneration in mice. Nat Commun4, 2932.

[46] Zlokovic BV (2011) Neurovascular pathways to neurodegenerationin Alzheimer's disease and other disorders. Nat RevNeurosci12, 723-738.

[47] Naveilhan P, Neveu I, Baudet C, OhyamaKY, BrachetP,WionD (1993) Expression of 25(OH) vitamin D3 24-hydroxylasegene in glial cells. Neuroreport5, 255-257.

[48] Milani C, Katayama MLH, de Lyra EC,Welsh J, Campos LT, Brentani MM,Maciel M, do S, Roela RA, del Valle PR, G'oes JCGS, Nonogaki S, Tamura RE, Folgueira MAAK (2013)Transcriptional effects of 1,25 dihydroxyvitamin $D(3)$ physiologicaland supra-physiological concentrations in breastcancer organotypic culture. BMC Cancer 13,119.

[49] Carlberg C, Seuter S, de Mello VDF, Schwab U, Voutilainen S, Pulkki K, NurmiT,Virtanen J, Tuomainen T-P, UusitupaM(2013) Primary vitamin D target genes allow a categorizationof possible benefits of vitamin D3 supplementation. PloS One8, e71042.

[50] Verlinden L, Kriebitzsch C, Eelen G, Van Camp M,Leyssens C, Tan BK, Beullens I, Verstuyf A (2013) Theodd-skipped related genes Osr1 and Osr2 are induced by1,25-dihydroxyvitamin D3. J Steroid BiochemMolBio/136,94-97.

[51] Lu J, Goldstein KM, Chen P, Huang S, Gelbert LM, NagpalS (2005) Transcriptional profiling of keratinocytes revealsa vitamin D-regulated epidermal differentiation network. JInvest Dermato/124, 778-785.

[52] Schmid C, Schl"apfer I, Gosteli-Peter MA, Hauri C, FroeschER, Zapf J (1996) 1 alpha,25dihydroxyvitamin D3 increasesIGF binding protein-5 expression in cultured osteoblasts. FEBS Lett 392, 21-24.

[53] Lee H, Bae S, Yoon Y (2012) Anti-adipogenic effects of 1,25-dihydroxyvitamin D3 are mediated by the maintenance of thewingless-type MMTV integration site/_-catenin pathway. Int

J Mol Med 30, 1219-1224.

[54] Nguyen NLH, Chen K, McAleerJ,Kolls JK (2013)VitaminDregulation ofOX40ligand in immune responses to Aspergillusfumigatus. Infect Immun81, 1510-1519.

[55] Smolders J, Schuurman KG, van Strien ME, Melief J, HendrickxD, Hol EM, van Eden C, Luchetti S, Huitinga I (2013)Expression of vitamin D receptor and metabolizing enzymesin multiple sclerosisaffected brain tissue. J NeuropatholExpNeurol72, 91-105.

[56] Afzal S, Bojesen SE, Nordestgaard BG (2014) Reduced25-hydroxyvitamin D and risk of Alzheimer's disease andvascular dementia. Alzheimers Dement 10, 296-302.

[57] Dickens AP, Lang IA, Langa KM, Kos K, Llewellyn DJ(2011) Vitamin D, cognitive dysfunction and dementia inolder adults. CNS Drugs 25, 629-639. 
[58] Johansson P, Almqvist EG, Johansson J-O, MattssonN, Andreasson U, Hansson O, Wallin A, Blennow K,Zetterberg H, Svensson J (2013) Cerebrospinal fluid(CSF) 25-hydroxyvitamin D concentration and CSF acetylcholinesteraseactivity are reduced in patients withAlzheimer's disease. PloS One 8, e81989.

[59] Wion D, MacGrogan D, Neveu I, Jehan F, Houlgatte R, BrachetP (1991) 1,25-Dihydroxyvitamin D3 is a potent inducerof nerve growth factor synthesis. J Neurosci Res 28, 110-114.

[60] Brown J, Bianco JL, McGrath JJ, Eyles DW (2003) 1,25-dihydroxyvitamin D3 induces nerve growth factor, promotesneurite outgrowth and inhibits mitosis in embryonic rat hippocampal neurons. Neurosci Lett 343, 139-143.

[61] Naveilhan P, Neveu I, Wion D, Brachet P (1996) 1,25-Dihydroxyvitamin D3, an inducer of glial cell line-derivedneurotrophic factor. Neuroreport7, 2171-2175.

[62] Griffin MD, Xing N, Kumar R (2003) Vitamin D and itsanalogs as regulators of immune activation and antigen presentation.AnnuRevNutr23, 117-145.

[63] Mathieu C, van Etten E, Decallonne B, Guilietti A, GysemansC, Bouillon R, Overbergh L (2004)

Vitamin D and 1,25-dihydroxyvitamin D3 as modulators in the immune system. JSteroid BiochemMolBiol89-90 449-452.

[64] Garcion E, Sindji L, Leblondel G, Brachet P, Darcy F (1999)1,25-dihydroxyvitamin D3 regulates the synthesis of gammaglutamyltranspeptidase and glutathione levels in rat primaryastrocytes. J

Neurochem73, 859-866.

[65] Furman I, Baudet C, Brachet P (1996) Differential expressionof M-CSF, LIF, and TNF-alpha genes in normal and malignantrat glial cells: Regulation by lipopolysaccharide and vitaminD. $J$ Neurosci Res 46, 360-366.

[66] Grammas P,OvaseR(2001) Inflammatory factors are elevatedin brain microvessels in Alzheimer's disease. Neurobiol Aging22, 837-842.

[67] Galimberti D, Fenoglio C, Lovati C, Venturelli E, Guidi I,Corr'a B, Scalabrini D, Clerici F, Mariani C, Bresolin N,Scarpini E (2006) Serum MCP-1 levels are increased in mildcognitive impairment and mild Alzheimer's disease. NeurobiolAging 27, 1763-1768.

[68] Westin K, Buchhave P, Nielsen H, Minthon L, JanciauskieneS, Hansson O (2012) CCL2 is associated with a faster rate ofcognitive decline during early stages of Alzheimer's disease.PloS One 7, e30525.

[69] Izikson L, Klein RS, CharolF, Weiner HL, Luster AD (2000)Resistance to experimental autoimmune encephalomyelitis inmice lacking the CC chemokine receptor (CCR)2. J Exp Med192, 1075-1080.

[70] Ishii N, Takahashi T, Soroosh P, Sugamura K (2010) OX40-OX40 ligand interaction in T-cellmediated immunity andimmunopathology. Adv/mmuno/105, 63-98.

[71] Xiao X, Balasubramanian S, Liu W, Chu X, Wang H,Taparowsky EJ, Fu Y-X, Choi Y, Walsh MC, Li XC (2012)OX40 signaling favors the induction of TH9 cells and airwayinflammation. Nat Immuno/13, 981990.

[72] Wang Y-H, Liu Y-J (2007) OX40-OX40L interactions: A promising therapeutic target for allergic diseases? J ClinInvest 117, 3655-3657.

[73] Carboni S, Aboul-Enein F, Waltzinger C, Killeen N, LassLassmann H, Pena-Rossi C (2003) CD134 plays a crucial role inthe pathogenesis of EAE and is upregulated in the CNS ofpatients with multiple sclerosis. J Neuroimmunol145, 1-11.

[74] Kaur D, Brightling C (2012) OX40/OX40 ligand interactionsin T-cell regulation and asthma. Chest 141, 494-499. 
[75] Karulf M, Kelly A, Weinberg AD, Gold JA (2010) OX40ligand regulates inflammation and mortality in the innateimmune response to sepsis. J Immuno/185, 4856-4862.

[76] Redmond WL, Weinberg AD (2007) Targeting OX40 andOX4OL for the treatment of autoimmunity and cancer. CritRev Immuno/27, 415-436.

[77] Furuhashi M, Ishimura S, Ota H, MiuraT(2011) Lipid chaperonesand metabolic inflammation. IntJ Inflam2011, 642612.

[78] Terra X, Quintero Y, Auguet T, Porras JA, Hern'andez M,Sabench F, Aguilar C, Luna AM, Del Castillo D, RichartC (2011) FABP 4 is associated with inflammatory markersand metabolic syndrome in morbidly obese women. Eur JEndocrino/164, 539-547.

[79] Shum BOV, Mackay CR, Gorgun CZ, Frost MJ, KumarRK, Hotamisligil GS, Rolph MS (2006) The adipocyte fattyacid-binding protein aP2 is required in allergic airway inflammation.J Clin Invest 116, 2183-2192.

[80] Andres Cerezo L, Kuklova M, Hulejova H, Vernerova Z,Pesakova V, Pecha O, Veigl D, Haluz'ik M, Pavelka K, Vencovsky J, Senolt L (2013) The level of fatty acid-bindingprotein 4, a novel adipokine, is increased in rheumatoid arthritisand correlates with serum cholesterol levels. Cytokine 64,441-447. [81] Morser J (2012) Thrombomodulin links coagulation toinflammation and immunity. Curr Drug Targets 13, 421-431.

[82] Conway EM (2012) Thrombomodulin and its role in inflammation.Seminlmmunopatho/34, 107125.

[83] Grey ST, Tsuchida A, Hau H, Orthner CL, Salem HH,Hancock WW (1994) Selective inhibitory effects of the anticoagulantactivated protein $\mathrm{C}$ on the responses of humanmononuclear phagocytes to LPS, IFN-gamma, or phorbolester. J Immuno/153, 3664-3672.

[84] Milner CM, Day AJ (2003) TSG-6: A multifunctional proteinassociated with inflammation. J Cell Sci116, 1863-1873.

[85] Shen B, Smith RS Jr, Hsu Y-T, Chao L, Chao J (2009)Kruppel-like factor 4 is a novel mediator of Kallistatin ininhibiting endothelial inflammation via increased endothelialnitric-oxide synthase expression. J BiolChem284, 35471-35478.

[86] AiW, LiuY, LangloisM,WangTC(2004) Kruppel-like factor4 (KLF4) represses histidine decarboxylase gene expressionthrough an upstream Sp1 site and downstream gastrin responsiveelements. J BiolChem279, 8684-8693.

[87] Liao X, Sharma N, Kapadia F, Zhou G, Lu Y, Hong H,Paruchuri K, Mahabeleshwar GH, Dalmas E, Venteclef N,Flask CA, Kim J, Doreian BW, Lu KQ, Kaestner KH, Hamik A, Cl'ement K, JainMK(2011) Kruppel-like factor 4 regulatesmacrophage polarization. J Clin Invest 121, 2736-2749.

[88] Thomas WE (1999) Brain macrophages: On the role of pericytesand perivascular cells. Brain Res Brain Res Rev 31,42-57.

[89] Kaushik DK, Mukhopadhyay R, Kumawat KL, Gupta M,Basu A (2012) Therapeutic targeting of Kruppel-like factor 4abrogates microglial activation. J Neuroinflammation9, 57.

[90] Sakuta H, Suzuki R, Takahashi H, Kato A, Shintani T, lemuraSi, Yamamoto TS, Ueno N, Noda M (2001) Ventroptin: ABMP-4 antagonist expressed in a double-gradient pattern inthe retina. Science 293, 111-115.

[91] Kane R, Godson C, O'Brien C (2008) Chordin-like 1, abone morphogenetic protein-4 antagonist, is upregulated byhypoxia in human retinal pericytes and plays a role in regulatingangiogenesis. Mol Vis 14, 1138-1148. 
[92] Li D, Tang J, Xu H, Fan X, Bai Y, Yang L (2008) Decreased hippocampal cell proliferation correlates withincreased expression of BMP4 in the APPswe/PS1DeltaE9mouse model of Alzheimer's disease. Hippocampus 18, 692-698.

[93] Ara J, See J, Mamontov P, Hahn A, Bannerman P, Pleasure D,Grinspan JB (2008) Bone morphogenetic proteins 4,6 , and7 are up-regulated in mouse spinal cord during experimental autoimmuneencephalomyelitis. J NeurosciRes86, 125-135.

[94] Jo H, Song H, Mowbray A (2006) Role of NADPH oxidasesin disturbed flow- and BMP4- induced inflammationand atherosclerosis. Antioxid Redox Signal 8, 1609-1619.

[95] Osborn L, Hession C, Tizard R, Vassallo C, Luhowskyj S, Chi-Rosso G, LobbR(1989) Direct expression cloning of vascularcell adhesion molecule 1 , a cytokine-induced endothelialprotein that binds to lymphocytes. Cell 59, 1203-1211

[96] KokovayE,WangY,KusekG,Wurster R, Lederman P, LowryN, Shen Q, Temple S (2012) VCAM1 is essential to maintainthe structure of the SVZ niche and acts as an environmentalsensor to regulate SVZ lineage progression. Cell Stem Cell11, 220-230.

[97] Sengillo JD, Winkler EA, Walker CT, Sullivan JS, JohnsonM, Zlokovic BV (2013) Deficiency in mural vascular cellscoincides with blood-brain barrier disruption in Alzheimer'sdisease. Brain Patho/23, 303-310.

[98] Pimentel-Coehlo PM, Rivest S (2012) the early contributionof cerebrovascular factors to the pathogenesis of Alzheimer'sdisease. Eur J Neurosci35, 1917-1937.

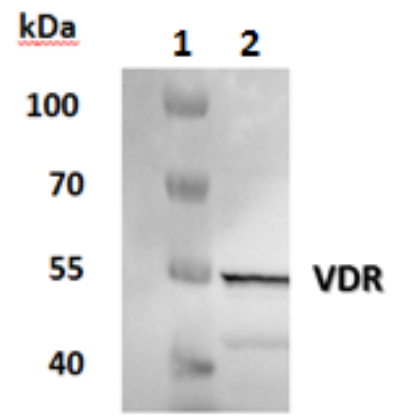

$\underline{A}$

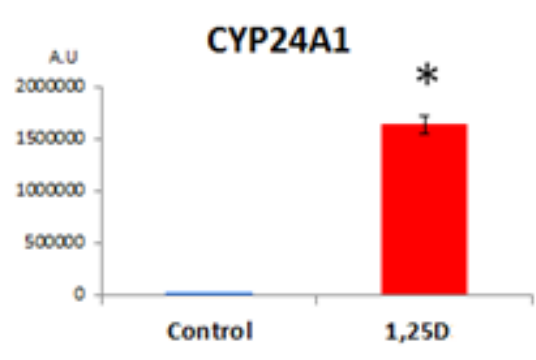

$\underline{B}$

Fig. 1. Human pericyte cells express VDR and respond to 1,25D3. A) Immunoblot showing the presence of VDR in human pericyte brain cellcultures. Lane 1, molecular weight markers; lane 2: pericyte cell lysate. The blot was incubated with the VDR antibody N20. B) RT-qPCR assay of the mRNA of the 1,25D inducible gene vitamin D 24-Hydroxylase (CYP24A1) demonstrates a significant increase in CYP24A1 mRNAamount when pericytes are cultured for 24 hours with 10-8 M 1,25D3. $(* p<0.005)$; A.U: arbitrary units. 


\begin{tabular}{|c|c|c|c|c|c|c|}
\hline Probe set ID & Gene Name & & Exp 1 & Exp 2 & Average & Ref \\
\hline 206504_at & cytochrome P450, family 24, subfamily A, & CYP24A1 & 158,2 & 355,8 & 237,2 & [24] \\
\hline 203868_s_at & vascular cell adhesion molecule 1 & VCAM1 & 3,4 & 3,2 & 3,4 & \\
\hline 218973_at & elongation factor Tu GTP binding domain & EFTUD1 & 3,0 & 3,8 & 3,4 & [25] \\
\hline 203887_s_at & thrombomodulin & THBD & 2,8 & 2,8 & 2,8 & [26] \\
\hline 213568_at & odd-skipped related 2 (Drosophila) & OSR2 & 2,0 & 3,7 & 2,7 & [27] \\
\hline 221841_s_at & Kruppel-like factor 4 (gut) & KLF4 & 2,3 & 3,1 & 2,7 & [28] \\
\hline 224762_at & serine incorporator 2 & SERINC2 & 2,2 & 3,4 & 2,7 & \\
\hline 206025_s_at & tumor necrosis factor, alpha-induced prot. & TNFAIP6 & 2,4 & 2,8 & 2,6 & \\
\hline 210002_at & GATA binding protein 6 & GATA6 & 2,4 & 2,4 & 2,4 & \\
\hline 206765_at & potassium inwardly-rectifying channel, s & KCNJ2 & 2,1 & 2,6 & 2,3 & \\
\hline 225532_at & $\mathrm{Cdk} 5$ and $\mathrm{Abl}$ enzyme substrate 1 & CABLES1 & 2,3 & 2,0 & 2,1 & \\
\hline 204345_at & collagen, type XVI, alpha 1 & COL16A1 & 1,5 & 2,4 & 1,9 & \\
\hline 229581_at & extracellular leucine-rich repeat and $\mathrm{fi}$ & ELFN1 & 1,7 & 2,1 & 1,9 & \\
\hline 209763_at & chordin-like 1 & CHRDL1 & 1,6 & 2,3 & 1,9 & \\
\hline 212190_at & serpin peptidase inhibitor, clade $\mathrm{E}$ & SERPINE2 & 1,9 & 1,6 & 1,7 & \\
\hline 211958_at & insulin-like growth factor binding protein & IGFBP5 & 1,7 & 1,8 & 1,7 & [29] \\
\hline 221872_at & retinoic acid receptor responder (tazaro & RARRES1 & 2,0 & 1,5 & 1,7 & \\
\hline 209840_s_at & leucine rich repeat neuronal 3 & LRRN3 & 1,7 & 1,7 & 1,7 & \\
\hline 200878_at & endothelial PAS domain protein 1 & EPAS1 & 1,6 & 1,7 & 1,7 & \\
\hline 216598_s_at & chemokine ( $\mathrm{C}-\mathrm{C}$ motif) ligand 2 & $\mathrm{CCL} 2$ & 0,6 & 0,7 & 0,7 & \\
\hline 203980_at & fatty acid binding protein 4 , adipocyte & FABP4 & 0,6 & 0,7 & 0,6 & [30] \\
\hline 207426_s_at & tumor necrosis factor (ligand) superfami & TNFSF4 & 0,6 & 0,6 & 0,6 & [31] \\
\hline 222862_s_at & adenylate kinase 5 & AK5 & 0,6 & 0,6 & 0,6 & \\
\hline 239909_at & ADAMTS-like 1 & ADAMTSL1 & 0,4 & 0,4 & 0,5 & \\
\hline
\end{tabular}

Table 1:List of differentially expressed genes in human brain pericyte cultures in the presence of $10^{-8}$ $M 1,25 D$ (average induction fold $\geq 1.7$ or $\leq 0.7$ compared to control cells). Fold changes are the average of two independent experiments. Published references for genes previously reported to be modulated by $1,25 \mathrm{D}$ are indicated. 

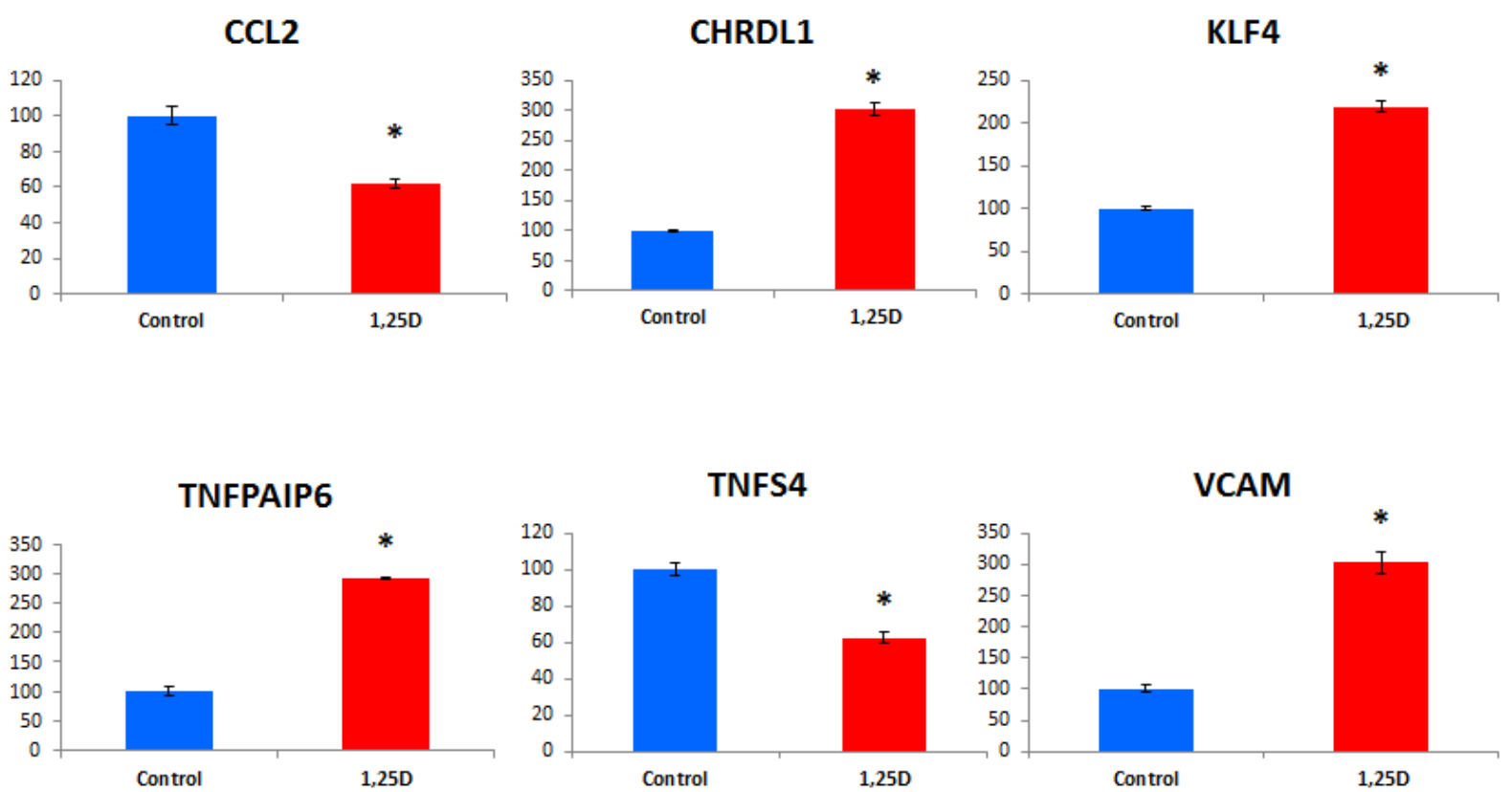

Fig. 2. Confirmatory RT-qPCR of the transcriptomic data for the genes newly identified as upregulated by $1,25 \mathrm{D}$ and involved in the regulationof inflammation. Results are depicted relative to control and normalized to actin and GAPDH mRNA. ( $* p<0.005$ compared to control). KLF4and TNFSF4, two genes previously described as induced by $1,25 \mathrm{D}[51,54]$, were included as positive control. CCL2, Chemokine (C-C motif)ligand 2; CHRDL1, chordin-like 1; KLF4, Kruppel-like factor 4; TNFAIP6, Tumor necrosis Factor, alpha-induced protein 6; TNFSF4, Tumornecrosis factor (ligand) superfamily member 4; VCAM, Vascular cell adhesion molecule 1.

\section{CYP27B1}

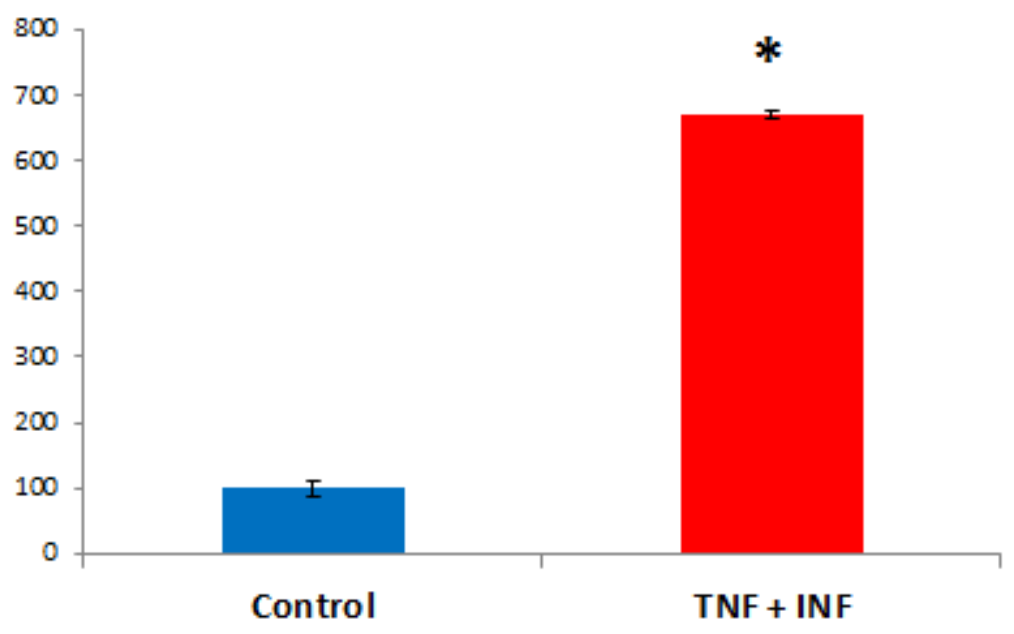


Fig. 3. TNF- $\alpha$ and Interferon- $\gamma$ induce the expression of 25-Hydroxyvitamin D3 1alpha-Hydroxylase (CYP27B1) in human brain pericytes. Human brain pericytes were cultured in the presence or absence of TNF- $\alpha(50 \mathrm{ng} / \mathrm{ml})$ and Interferon- $\gamma(50 \mathrm{ng} / \mathrm{ml})$ for 24 hours. Then RNA were extracted and CYP27B1 expression quantified by RT-qPCR. ( $* p<0.005$ compared to control). 